Rafidain Journal of Science

Vol. 29, No. 4, pp.23-31, 2020

DOI : 10.33899/rjs.2020.167310

Review Article

$\underline{\text { https://rsci.mosuljournals.com }}$

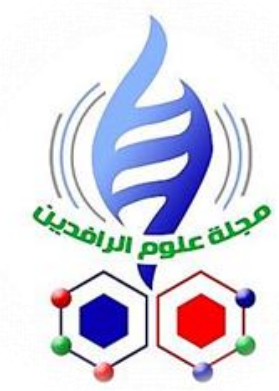

ISSN: 1608-9391

e-ISSN: 2664-2786

Received:8/10/2020

Accepted:27/10/2020

\section{Role of the Hairy Roots as A Biological Agent in Phytoremediation}

Amjad A. Mohammed* Owayes M. Hamed Raed S. Alsaffar

Department of Biology/ College of Science/ University of Mosul

*Email: amjsbio33@uomosul.edu.iq

\section{Environmental pollution}

Pollution is a growing undertaking for humans around the globe which affects in which affects both developed and growing towns (Suresh and Ravishankar, 2004). All herbal methods that make contributions to economic pollution are typically categorized as natural contaminants (Sosa Alderete et al., 2009). These are the human final products which include: navy explosives, agriculture, oil products, gasoline manufacturing and wood results (Pilon-Smits, 2005). Subsequently, the natural activities can additionally sell the discharge of heavy metals as nickel, molybdenum, lead, copper, zinc and mercury to the environment which are harmful to human health (Nedelkoska and Doran, 2000). The whole surroundings are constantly being contaminated from pollutants which is unsafe for human fitness (Suza et al., 2008 ; Rezek et al., 2012).

The cost of cleansing up infected sites is high therefore using vegetation to extract, stabilize and degrade contaminants, all of them called as phytoremediation, is giving reputation as an extra costpowerful opportunity to different strategies of cleanup (Kuiper et al., 2004). 


\section{Plants Used for Removing the Environmental Contaminants}

Many plants are used to treat and destroy most of environmental pollutants (Kagalkar et al., 2009). Also in phytoremediation studies, plant tissue culture plays a vital position and complements our understanding of plant metabolisms (Abhilash et al., 2009; Bhargava et al.,2018).

Tissue life style gives extra benefits, now the experimental convenience is not so much effective, but is additionally value-powerful, easier, much less complicated, and quicker when compared to the entire plant gadget. Plant roots may additionally act in the absorption as conduit of a pollutant then translocate with the vascular system and focused in tissues by a procedure known as phytoextraction (Doty, 2008). Oats might also secretly exudates in flip which offer a haven for microbial increase represent a nutrient supply for the microbes (Bais et al., 2006). The ensuing rhizospheric contact can also decorate the biodegradation of natural pollutants in a procedure known as phytostimulation (Pilon-Smits, 2005). The contaminant can also end up goal for degradation via secreted the plant enzymes (Boominathan et al., 2004). Plants are used in plant treatment to provide optimal conditions for microbial activity towards extracted pollutants that can be transferred through the plant (Tamaoki et al., 2008). In phytoremediation, vegetation offers important benefits; they act as the optimum state for root colonizing microorganism and also offer a simple price-powerful method of accumulate pollutants (Suresh and Ravishankar, 2004). The root system represents the contact region between plant tissues and pollutants in the environment (soil or water), thus it has the ability for the phytoremediation (Xingmao and Burken, 2003). The ground part of a plant gadget where in roots are in touch with the microorganisms is called rhizosphere (Walker et al., 2003). The interaction between plant, microbes and mycorrhizal colonies is regulated by root exudates (Bais et al., 2006; Chandra, 2012). In this sense, root exudates are crucial materials for degradation the pollutants using microbe's rhizosphere (Rentz et al., 2005, Barea et al., 2005; Suza et al., 2008).

Hairy roots are exceptional fibrous which are formed on tissues as a result of infection with Agrobacterium rhizogenes, a diseases soil bacterium (Georgiev et al., 2007; Veena and Taylor, 2007). When cell is infected, A. rhizogenes plasmid genes transfers to the plant cell genome ensuing in the structure adjustments within the host cell main to enhanced boom in the media which free from hormone (Suza et al., 2008). The metabolism capacity of hair roots can be manipulated to induce de novo synthesis of excessive phytochemicals (Guillon et al., 2006).

Based on the sort of biological techniques used through flora to remove pollutants phytoremediation Fig. (1) is classed in to many techniques as phytoextraction, phytotransformation, phytostabilization, phytovolatilization, rhiyzofiltration, or phytostimulation (Pilon-Smits, 2005; Abhilash et al.,2009). In general, plant life use methods that collectively make a contribution to the major stage of bioremediation (Tangahu et al., 2011; Rajkumar et al., 2012). Phytoremediation through hairy root lifestyle: removal of environmental contaminants uptake of metals or contaminants depends on several factors together with bioavailability of the metals, chemical properties of the pollutant, plant species, chelating agent added, root quarter environmental conditions, etc. (Tangahu et al., 2011). 


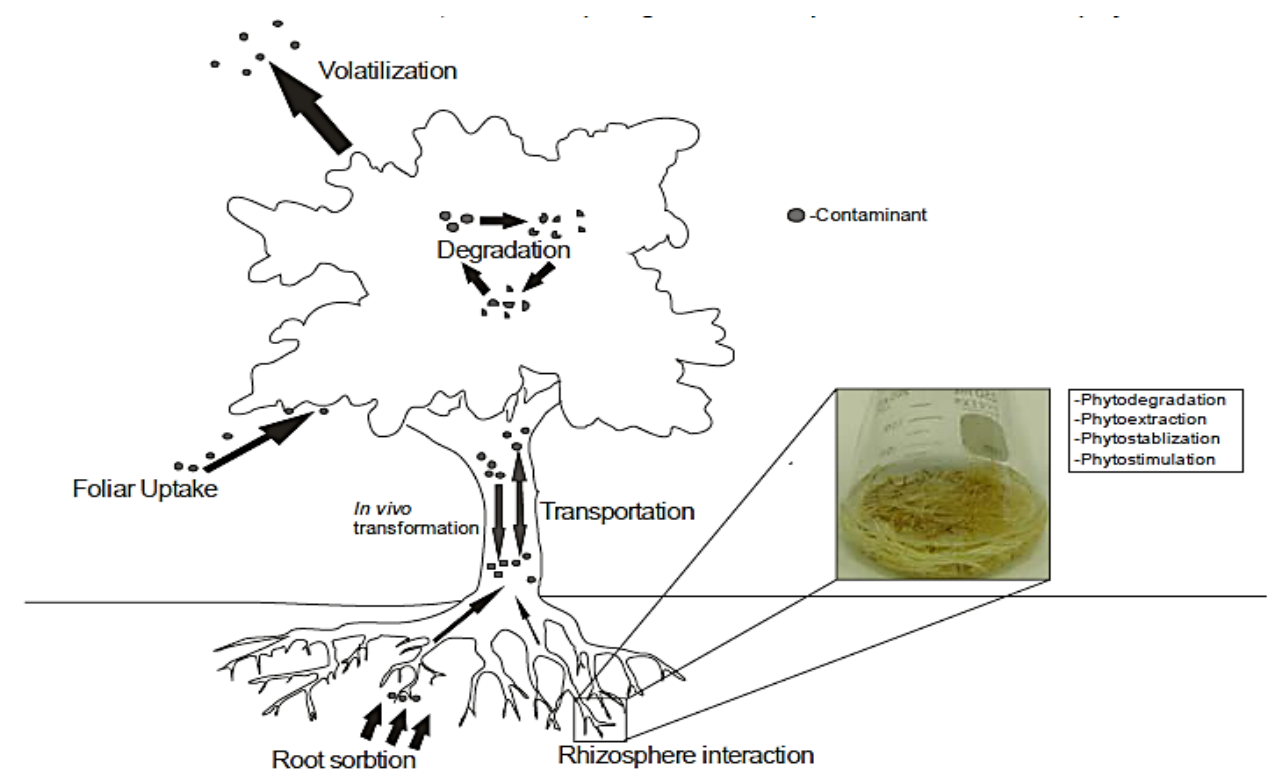

Fig. 1: The methods of plants for phytoremediation

Pollutants are absorbed from the soil by the root hairs surrounding them or nearby, which are transported and destroyed inside the plant or volatilized from it to the air. The hairy roots are a powerful tool for studying biological activities in the plants phytoremediation processes (Suza et al., 2008).

Nature always attempts to stabilize the environmental constituents by the natural means. Plants have the capacity to trap many toxins and can bring back the equilibrium status. Chelating agents may be used for the treatment of toxic metals poisoning. For taking a look at phytoremediation, the bushy-root cultures have been successfully used as a version in in vitro structures. Researchers said that the majority of metals accumulated within the roots in many flowers (Pickering et al., 2000).

\section{Hairy Roots: Characteristics, Benefits and Applications}

Hairy-root cultures evolved via genetic transformation through A. rhizogenes infection confirmed many special features, which include limitless branching, genetic and biochemical stability and high boom price ( $\mathrm{Hu}$ and $\mathrm{Du}, 2006)$. A. rhizogenes is a Gram-negative bacterium belong to the sam family Rhizobiaceae. Wounded sites of flowers are the contamination site of $A$. rhizogenes and finally induce the formation of thread-like structures (hairy roots) in several groups of plant types (Flocco and Giulietti, 2007). With the infection process, T-DNA genes (10-30 kb) of A. rhizogenes transfers to the plant genome, this is a part of the root inducing plasmids (pRi) (Giri and Narasu, 2000; Agostini et al., 2003; Coniglio et al., 2008). The hairy roots have the pleiotropic root boom, lateral branches and the excessive number of root hairs and tissues also have rather differentiated and purposeful root organs. These roots also have a higher enzymatic degradation capacity because of the presence of various enzymes including peroxidase, lactase and oxygenase (Talano et al., 2003; Telke et al., 2011). Regeneration of plants can be done easily from the differentiation of those roots. Also have functionality unlimited growth in boom hormone- free lifestyle media (Rao and Ravishankar, 2002). It is meant that the genes auxl and aux2 are accountable for the auxin autotrophy of hairy roots (Santos-Diaz, 2013). Although hairy roots have an exceptional morphology when compared to normal roots, they act as a vital manufacturing machine for manufacturing secondary metabolites. (Sharma et al., 2013). Beside the above specificity, hairy roots also are used for screening, tolerance, accumulation and elimination of environmental pollution (Agostini et al., 2013; Kagalkar et al., 2009). Hairy roots of numerous vegetation have been used for the reason of phytoremediation, especially for the natural and metallic pollution. 
Table: Removal of Metals by Using Hairy-Root Cultures

\begin{tabular}{|c|c|c|c|}
\hline S. No. & Plant's Name & Pollutants & References \\
\hline 1 & $\begin{array}{c}\text { Adenophora lobophylla, Adenophora } \\
\text { potaninii }\end{array}$ & Cadmium & (Wu et al., 2001) \\
\hline 2 & Alyssum species & Nickel & (Nedelkoska and Doran, 2001) \\
\hline 3 & Alyssum bertolonii & Nickel & (Bhoominathan and Doran, 2002) \\
\hline 4 & Alyssum murale & Nickel & (Vinterhalter et al., 2008) \\
\hline 5 & Armoracia rusticana & Uranium & (Soudek et al., 2011) \\
\hline 6 & Cucumis sativus & Cadmium & (Zhang et al., 2009) \\
\hline 7 & Daucus carota & Uranium & (Straczek et al., 2009) \\
\hline 8 & $\begin{array}{c}\text { Hyptis capitata, } \text { Polycarpaea } \\
\text { longiflora, } \text { Euphorbia } \text { sp. }\end{array}$ & Copper & (Boominathan and Doran, 2003) \\
\hline 9 & Nicotiana tabacum & Nickel & (Georgiev et al., 2007) \\
\hline 10 & Lycopersicon esculentum & Phenol & \\
\hline
\end{tabular}

Mechanisms of remediation utilized by bushy root culture hairy roots subculture confirmed different mechanisms for the uptake of metals that is additionally similar to the plant mechanisms (Bharagava et al., 2017). Few commonplace mechanisms are suggested for the uptake of metals and every so often flowers or bushy roots select particular mechanisms for the minute metals or pollutants. Different plants also have the one-of-a-kind quantity of tolerance limits for a specific pollutant. Hairy-root cultures are commonly used for the remediation of cadmium (Cd), nickel (Ni), zinc $(\mathrm{Zn})$, uranium $(\mathrm{U})$, copper $(\mathrm{Cu})$, and organic pollutants. (Singh, et al., 2006; Yadav et al., 2017).

Hairy roots give numerous benefits for phytoremediation research, including: their rapidly grow in -unfastened conditions, offering a surface place of contact among many pollutants that strong in contrast to normal kind (Gujarathi et al., 2005; Georgiev et al., 2007). Hairy roots improve the genetic transformation and have ability to supply big parts of exudates which might be consist of enzymes and many metal chelating compounds which could remove the harmful contaminants both organic and inorganic (Badhra et al., 2001). The periwinkle (Catharanthus roseus) hairy roots have an "intrinsic ability" to take away these compounds from the environment (Bais et al., 2006). Recently, bushy roots were used to test vegetation for its ability to remove excessive stages of phenols (De Araujo et al., 2002), which are typically utilized in cultural programs and petroleum products that pose a risk to human (Agostini et al., 2003; Coniglio et al., 2008).

The hairy roots induced from different types of plant have peroxidase enzymes act as efficiency factor for removing phenol and chlorophenols from the subculture media (González et al., 2006; Singh et al., 2006). There are other plants using many mechanisms to benefit from phenol. For example: hairy roots of carrot and candy potato by its ability to connect phenolic compounds with polar cellular materials (may be sugars and proteins) as well as with insoluble substances which include mobile walls and membranes (Pavli et al., 2010). The capability of vegetation to remove contaminants will depend upon the different defensive mechanisms that can prolong tissue survival and biochemical traits of metabolizing enzymes (De Araujo et al., 2004; Chandra, 2012). The inclusion of metals in plant tissues are crucial elements of the capability of plants to dispose of heavy metals from the soil (Violante et al., 2010; Santos-Diaz 2013). Hairy roots have been proven to be used as a way to examine a wild type of many plant species from their ability to extract various metals (Nedelkoska and Doran, 2000; Ibañez et al., 2011).

Hairy roots of alpine penny grass (Thlaspica erulescens) used to extract and gather cadmium in combination with natural acids within the components of the cell (Boominathan and Doran, 2003a; Agostini et al. 2013). There is an attention to the harmful effects of the continuously use of the insecticide DDT (Sadasivaiah et al., 2007) in many studies recommend that DDT might have bad outcomes on human (Hatcher et al., 2008). Hairy roots of chicory (Cichoriumin tybus) and 
Indian mustard (Brassica juncea) have the ability to dispose of DDT from contaminated web sites. Specially, $C$. intybus and B. juncea may produce enzymes that can degrade DDT as a result of a promising opportunity for the characterization of those enzymes (Suresh et al., 2005). This mammalian enzyme is used to generate vegetation with the ability to eliminate diverse natural pollutants from the air. For example, a hairy root of Lycopersicum esculentum tpxl gene by overexpressing encoding a peroxidase which generat roots with enhanced ability of casting off phenol from the environment (Wevar-Oller et al., 2005; Bernejee et al., 2002). The transgenic approaches can produce plants with modern phytoremediation capacity (Van Aken, 2008). It is vital to limit the release of pesticides and antibiotics into the surroundings and is important to identify the strategies for cleanup inside the case of infection. Hairy roots of sunflower (Helianthus annuus) are able to extract and metabolize antibiotics together with tetracycline and oxtetracycline to contain reactive oxygen intermediates (Gujarathi and Linden, 2005; Talano et al., 2012). However, the ability of plants for environmental remediation regulated with the way of plant metabolic pathways, the main variety of enzymes activity and tolerance tools (Bhargava et al., 2012). In this field, hairy roots are often used in phytoremediation research as version plant structures due to the fact that they permit the analysis of the pure metabolic associated with the plant cells and their abilities for toxicity tolerance (Van Nevel et al., 2007; Doran, 2009; Ma et al.,2011). During the last years, hairy roots have contributed to our information of the complicated molecular and biochemical mechanisms in phytoremediation. In the existing tiny-overview, we examined the greatest applicable research associated with the utility of hairy roots with the purpose of detecting the capacity of plant cells to tolerate, detoxify, metabolize, and save many kinds of natural and inorganic pollutants. The areas in hairy roots offer the greatest capacity for the practical method of phytoremediation techniques and mechanisms might be defined and current developments are included. Hairy roots have proved to be a totally suitable tool and important version method to look the detoxification and the interest of central cleansing enzymes, without the intrusion of soil medium and microorganisms. Hairy roots expand in an economy that is completely without infection by microbes and may be used to differentiate the responses and skills of plant cells from the infection by rhizospheric microbes (Wu et al., 2010 ; Telke et al., 2011). Thus, hairy roots are able of metabolize according to several mixtures by way of commonplace metabolic ways which represent an extra benefit to this plant system (Nepovim et al., 2004; Angelini et al., 2011).

\section{CONCLUSIONS}

Hairy roots arise from different species of plant as a result of being infected with different strains of A. rhizogenes. This technology serves stable production of important pharmaceutical compounds as well as other high-value products. The environmental pollution affects the local and global human societies. Therefore, it was necessary to get rid of these pollutants. The plants are one of the most important ways of being natural and tend to remove the environment and provide an exceptional ability to absorb pollutants and convert them into useful compounds within their bodies or liberate their harmless wastes to the atmosphere after destroying them. The use of genetically transformed hairy roots in plant treatment is highly efficient because of the characteristics of the roots in terms of laboratory access, rapid growth and many branches, as well as the ability to control their genes and thus obtain a distinctive biological tool in this field.

\section{REFERENCES}

Abhilash, P.C.; Jamil, S.; Singh, N. (2009). Transgenic plants for enhanced biodegradation and phytoremediation of organic xenobiotics. Biotechnol. Adv., 27, 474-488.

Agostini, E.; Coniglio, M.S.; Milrad, S.R.; Tigier, H.A.; Giulietti, A.M. (2003). Phytoremediation of 2,4- dichlorophenol by Brassica napushairy root cultures. Biotechnol. Appl. Biochem., 37, 139-144. 
Angelini, V.A.; Orejas, J.; Medina, M.I.; Agostini, E. (2011). Scale up of 2,4- dichlorophenol removal from aqueous solutions using Brassica napus hairy roots. J. Hazard Mater., 85, 269-274.

Bais, H.P.; Weir, T.L.; Perry, L.G.; Gilroy, S.; Vivanco, J.M. (2006). The role of root exudates in rhizosphere interactions with plants and other organisms. Annu. Rev. Plant Biol., 57, 233266.

Barea, J.; Pozo, J.M.; Azcón, R.; Azcón-Aguilar, C. (2005). Microbial cooperation in the rhizosphere. J. Expt. Bot., 56, 1761-1778.

Bernejee, S.; Shang, T.Q.; Wilson, A.M.; Moore, A.L.; Strand, S.E.; Gordon, M.P.; Doty, S.L. (2002). Expression of functional mammalian P450 2E1 in hairy root cultures. Biotechnol. Bioeng., 77, 462-466.

Bhadra, R.; Wayment, D.G.; Williams, R.K.; Barman, S.N.; Stone, M.B.; Hughes, J.B.; Shanks, J.V. (2001). Studies on plant-mediated fate of the explosives RDX and HMX. Chemosphere., 44, 1259-1264.

Bharagava, R.N.; Mishra, S. (2018). Hexavalent chromium reduction potential of Cellulosimicrobium sp. isolated from common effluent treatment industries. Ecotoxicol. Environm. Safety.,147, 102-109.

Bharagava, R.N.; Chowdhary, P.; Saxena, G. (2017). Bioremediation: An Eco-sustainable Green Technology, it's Applications and Limitations. In: Bharagava, R.N. (Ed.), Environmental Pollutants and their Bioremediation Approaches. CRC Press, Taylor and Francis Group, USA.

Bhargava, A.; Carmona, F.F.; Bhargava, M.; Srivastava, S. (2012). Approaches for enhanced phytoextraction of heavy metals. J. Environ. Manage. ,105,103-120.

Boominathan, R.; Saha-Chaudhury, N.M.; Sahajwalla, V.; Doran, P.M. (2004). Production of nickel bio-ore from Hyper accumulator plant biomass: applications in phytomining. Biotechnol. Bioeng., 86, 243-250.

Boominathan, R.; Doran, P.M. (2002). Ni-induced oxidative stress in roots of the Ni Hyper accumulator, Alyssum bertolonii. New Phytology.,156, 205-215.

Boominathan, R.; Doran, P.M. (2003). Cadmium tolerance and anti-oxidative defenses in hairy roots of the cadmium Hyper accumulator. Thlaspi caerulescens. Biotechnol. Bioeng., 83,158-167.

Chandra, S. (2012). Natural plant genetic engineer Agrobacterium rhizogenes: role of T-DNA in plant secondary metabolism. Biotechnol. Lett., 34, 407-415.

De Araujo, B.S.; Charlwood, V.B.; Pletsch, M. (2002). Tolerance and metabolism of phenol and chloro derivatives by hairy root cultures of Daucus carotaL. Environ Pollut., 117, 329335.

Doty, S.L. (2008). Enhancing phytoremediation through the use of transgenics and endophytes. New Phytol., 179, 318-333.

Flocco, C.G.; Giulietti, A.M. (2007). "In vitro Hairy Root Cultures as a Tool for Phytoremediation Research”. In: Willey, N. (Ed.), Phytoremediation Methods in Biotechnology, Vol. 23. Wiley Humana, Totowa, NJ, pp. 161-173.

Georgiev, M.I.; Pavlov, A.I.; Bley, T. (2007). Hairy root type plant in vitro systems as sources of bioactive substances. App. Microbiol. Biotechnol.,74, 1175-1185.

Giri, A.; Narasu, L. (2000). Transgenic hairy roots: Recent trends and applications. Biotechnol. Advan.,18, 1-22.

González, P.S.; Capozucca, C.E.; Tigier, H.A.; Milrad, S.R.; Agostini, E. (2006). Phytoremediation of phenol from wastewater, by peroxidases of tomato hairy root cultures. Enzyme Microbial Technol., 39, 647-653.

Guillon, S.; Trémeouillax-Guiller, J.; Pati, P.K.; Rideau, M.; Gantet, P. (2006). Hairy root research: Recent scenario and exciting prospects. Curr. Opin. Plant Biol., 9, 341- 346. 
Gujarathi, N.P.; Haney, B.J.; Park, H.J.; Wickramasinghe, S.R.; Linden, J.C. (2005). Hairy roots of Helianthus annuus: a model system to study phytoremediation of tetracycline and oxytetracycline. Biotechnol. Prog., 21, 775-780.

Gujarathi, N.P.; Linden, J.C. (2005). Oxytetracycline inactivation by putative reactive oxygen species released to nutrient medium of Helianthus annuushairy root cultures. Biotechnol. Bioeng., 92, 393-402.

Hatcher, J.M.; Delea, K.C.; Richardson, J.R.; Pennell, K.D.; Miller, G.W. (2008). Disruption of dopamine transport by DDT and its metabolites. Neurotoxicol., 29, 682-690.

Hu, Z.B.; Du, M. (2006). Hairy root and its application in plant genetic engineering. J. Integrative Plant Biol.,48, 121-127.

Kagalkar, A.N.; Jagatap, U.B.; Jadhav, J.P.; Bapat, V.A.; Govindwar, S.P. (2009). Biotechnological strategies for phytoremediation of the sulphonatedazo dye Direct Red 5B using Blumea malcolmii Hook. Bioresour Technol., 100, 4104-4110.

Kuiper, I.; Lagendijk, E.L.; Bloemberg, G.V.; Lugtenberg, B.J. (2004). Rhizoremediation: a beneficial plant-microbe interaction. Mol. Plant Microbe Interact., 17, 6-15.

Ma, Y.; Prasad, M.N.V.; Rajkumar, M.; Freitas, H. (2011). Plant growth promoting rhizobacteria and endophytes accelerate phytoremediation of metalliferous soils. Biotechnol. Adv., 29, $248-258$.

Nedelkoska, T.V.; Doran, P.M. (2000). Hyper accumulation of cadmium by hairy roots of Thlaspi caerulescens. Biotechnol. Bioengineer., 67, 607-615.

Nedelkoska, T.V.; Doran, P.M. (2001). Hyper accumulation of nickel by hairy roots of Alyssum species: Comparison with whole regenerated plants. Biotechnol. Progress., 17, 752-759.

Nepovim, A.; Podlipná, R.; Soudek, P.; Schröder, P.; Vanek, T. (2004). Effects of heavy metals and nitroaromatic compounds on horseradish glutathione S-transferase and peroxidase. Chemosphere., 57, 1007-1015.

Pavli, O.I.; Panopoulos, N.J.; Goldbach, R.; Skaracis, G.N. (2010). BNYVV derived dsRNA confers resistance to rhizomania disease of sugar beet as evidenced by a novel transgenic hairy root approach. Transgenic Res., 19, 915-922.

Pickering, I.J.; Prince, R.C.; George, M.J.; Smith, R.D., George, G.N.; Salt, D.E. (2000). Reduction and coordination of arsenic in Indian mustard. Plant Physiol.,122, 1171-1177.

Pilon-Smits, E. (2005). Phyotoremediation. Annu. Rev. Plant Biol., 56, 15-39.18-Nedelkoska, T.V.; Doran, P.M. (2000). Characteristics of heavy metal uptake by plant species with potential for phytoremediation and phytomining. Minerals Eng., 13, 549-561.

Rajkumar, M.; Sandhya, S.; Prasad, M.N.V.; Freitas, H. (2012). Perspectives of plant-associated microbes in heavy metal phytoremediation. Biotechnol. Adv., 30(6), 1562-1574.

Rao, R.S.; Ravishankar, G.A. (2002). Plant cell cultures: Chemical factories of secondary metabolites. Biotechnol. Advan., 20, 101-153.

Rentz, J.A.; Alvarez, P.J.J.; Schnoor, J.L. (2005). Benzo [a]pyrene co-metabolism in the presence of plant root extracts and exudates: Implications for phytoremediation. Environ. Pollut., 136, $477-484$

Rezek, J.; Macek, T.; Doubsky, J.; Mackova, M. (2012). Metabolites of 2,20-dichlorobiphenyl and 2,6-dichlorobiphenyl in hairy root culture of black nightshade Solanum nigrum SNC-9O. Chemosphere., 89, 383-388.

Santos-Diaz, M.D.S. (2013). Metal remediation via in vitro root cultures. Plant-Based Remediation Process, Soil Biol., 35, 101-115, Springer-Verlag Berlin Heidelberg.

Sharma, P.; Padh, H.; Shrivastava, N. (2013). Hairy root cultures: A suitable biological system for studying secondary metabolic pathways in plants. Engineer. in Life Sci.,13, 62-75.

Singh, O.V.; Labana, S.; Pandey, G.; Budhiraja, R.; Jain, R.K. (2003). Phytoremediation: An overview of metallic ion decontamination from soil. Appl. Microbiol. Biotechnol., 61, $405-412$. 
Singh, S.; Melo, J.S.; Eapen, S.; D' Souza, S.F. (2006). Phenol removal using Brassica juncea hairy roots: Role of inherent peroxidase and $\mathrm{H} 2 \mathrm{O} 2$. J. Biotechnol.,123, 43-49.

Sosa Alderete, L.G.; Talano, M.A.; Ibañez, S.G.; Purro, S.; Agostini, E.; Milrad, S.; Medina, M.I. (2009). Establishment of transgenic tobacco hairy roots expressing basic peroxidases and its application for phenol removal. J. Biotechnol., 139, 273-79.

Soudek, P.; Petrova, S.; Benesova, D.; Vanek, T. (2011). Uranium uptake and stress response of in vitro cultivated hairy root culture of Amoracia rusticana. Agrochimica.,60, 15-28.

Straczek, A.; Wannijn, J.; Van-Hees, M.; Thijs, H.; Tiry, Y. (2009). Tolerance of hairy roots of carrots to $\mathrm{U}$ chronic exposure in standardized in vitro device. Environment. Experiment. Bot., 65, 82-89.

Subroto, M.A.; Priambodo, S.; Indrasti, N.S. (2007). Accumulation of zinc by hairy root cultures of Solanum nigrum. Biotechnol., 6, 344-348.

Suresh, B.; Ravishankar, G.A. (2004). Phytoremediation a novel and promising approach for environmental clean-up. Crit. Rev. Biotechnol., 24, 97-124.

Suresh, B.; Bais, H.P.; Raghavarao, K.S.M.S.; Ravishankar, G.A.; Ghildyal, N.P. (2005). Comparative evaluation of bioreactor design using Tagetes patulaL. hairy roots as a model system. Process Biochem., 40, 1509-1515.

Suza, W.; Harris, R.S.; Lorence, A. (2008). Hairy roots: from high-value metabolite production to phytoremediation. Electronic J. Integrat. Biosci., 3(1), 57-65.

Talano, M.A.; Agostini, E.; Medina, M.I.; Milrad-de-Forchetti, S.; Tigier, H.A. (2003). Tomato (Lycopersicon esculentumcv. Pera) hairy root cultures: Characterization and changes in peroxidase activity under $\mathrm{NaCl}$ treatment. In Vitro Cellular and Developmental BiologyPlant., 39, 354-359.

Talano, M.A.; WevarOller, A.L; González, P.S.; Agostini, E. (2012). Hairy roots, their multiple applications and recent patents. Recent Patents Biotechnol., 6,115-133.

Tamaoki, M.; Freeman, J.L.; Pilon-Smits, E.A.H. (2008). Cooperative ethylene and jasmonic acid signaling regulates selenite resistance in Arabidopsis. Plant Physiol., 146, 1219-1230.

Tangahu, B.V.; Abdullah, S.R.S.; Basri, H.; Idris, M.; Anuar, N.; Mukhlisin, M. (2011). A review on heavy metals $(\mathrm{As}, \mathrm{Pb}$, and $\mathrm{Hg}$ ) uptake by plants through phytoremediation. Internation. J. Chemical Engineer., 31.

Telke, A.A.; Kagalkar, A.N.; Jagtap, U.B.; Desai, N.S.; Bapat, V.A.; Govindwar, S.P. (2011). Biochemical characterization of lactase from hairy root culture of Brassica juncea L. and role of redox mediators to enhance its potential for the decolorization of textile dyes. Planta., 234,1137-1149.

Van Aken, B. (2008). Transgenic plants for phytoremediation: helping nature to clean up environmental pollution. Trends Biotechnol., 26, 25- 227.

Veena, V.; Taylor, C.G. (2007). Agrobacterium rhizogenes: Recent developments and promising applications. In Vitro Cell Dev. Biol., 43, 383-403.

Vinterhalter, B.; Savić, J.; Platiša, J.; Raspor, M.; Ninković, S.; Mitić, N.; Vinterhalter, D. (2008). Nickel tolerance and Hyper accumulation in shoot cultures regenerated from hairy root cultures of Alyssum murale Waldstet Kit. Plant Cell Tiss. Organ Cult., 94, 299-303.

Violante, A.; Cozzolino, V.; Perelomov, L.; Caporale, A.G.; Pigna, M. (2010). Mobility and bioavailability of heavy metals and metalloids in soil environments. J. Soil Sci. Plant Nutrit., 10, 268-292.

Walker, T.S.; Bais, H.P.; Halligan, K.M. (2003). Metabolic profiling of root exudates of Arabidopsis thaliana. J. Agric. Food Chem., 51, 2548-2554.

Wevar-Oller, A.L.; Agostini, E.; Talano, M.A.; Capozucca, C.; Milrad, S.R.; Tigier, H.A.; Medina, M.I. (2005). Overexpression of a basic peroxidase in transgenic tomato (Lycopersicon esculentum Mill. cv. Pera) hairy roots increases phytoremediation of phenol. Plant Sci.,169, 1102-1111. 
Wu, G.; Kang, H.B.; Zhang, X.Y.; Shao, H.B.; Chu, LY.; Ruan, C.J. (2010). A critical review on the bioremoval of hazardous heavy metals from contaminated soils: issues, progress, ecoenvironmental concerns and opportunities. J. Hazard Mater., 174, 1-8.

Xingmao, M.; Burken, J.G. (2003). TCE Diffusion to the atmosphere in phytoremediation applications. Environ. Sci. Technol., 37, 2534-2539.

Yadav, A.; Chowdhary, P.; Kaithwas, G.; Bharagava, R.N. (2017). Toxic metals in the environment, their threats on ecosystem and bioremediation approaches. In: Das, S.; Singh, H.R. (Eds.), "Handbook of Metal-Microbe Interaction and Bioremediation". CRC Press, Taylor and Francis Group, USA, pp. 128-141.

Zhang, Y.; Shi, H.; Po, E.; Tsang, K. (2009). Influences of heavy metal cadmium alone and in combination with zinc on the growth and activities of antioxidant enzymes of Cucumis sativus hairy roots. Chinese J. Biotechnol., 25, 60-68.

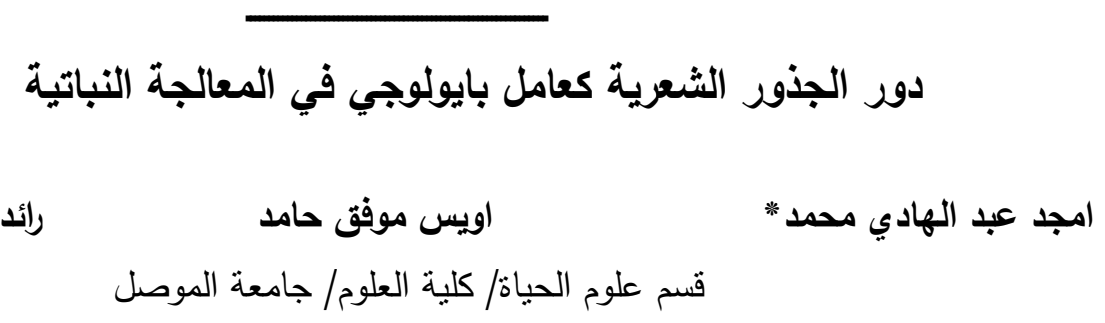

*Email: amjsbio33@uomosul.edu.iq 